(C) Syzyi M., Shevchenko O., Lykhman V., Shevchenko V., Kulyk I., 2018 Maksim Syzyi

Kharkiv National Medical University

Oleksandr Shevchenko

Kharkiv National Medical University

Victor Lykhman

State Institution «V. T. Zaitsev Institute of General and

Emergency Surgery of NAMS of Ukraine»

Vladislav Shevchenko

Kharkiv National Medical University

Igor Kulyk

Kharkiv National Medical University

\title{
TACTICS OF SURGICAL TREATMENT FOR INJURIES OF PHARYNX AND CERVICAL ESOPHAGUS
}

The results of surgical treatment of 98 patients with penetrating injuries to the pharynx and cervical esophagus are presented. The patients were divided into 2 groups - the main and the comparison group. In the comparison group, the traditional principles of intervention were used. In the main group, surgical intervention was performed with a mini access on the neck 3-4 cm in length using a ring-shaped retractor. In the main group there was a twofold decrease in the frequency of purulent complications in comparison with the comparison group.

Keywords: neck, injurie, pharynx, cervical esophagus.

\section{Introduction}

Penetrating injuries to the pharynx, esophagus and large blood vessels take a leading position in the structure of the neck wounds, wherein more than $50 \%$ of perforations occur in the cervical esophagus $[2 ; 5]$.

«Vivid» symptoms of injuries to large blood vessels and respiratory tract mask injuries to the pharynx and esophagus, which complicate the timely diagnosis of the injury. The correct diagnosis is established only after the onset of purulent complications that develop in $28-78 \%$ of patients with perforation of the cervical esophagus $[4 ; 6]$.

Late diagnosis of injury to the pharynx and cervical esophagus significantly worsens treatment outcomes. When revealing perforation of the esophagus in the first day after injury, the mortality is $8-9 \%$, and at a later diagnosis - 25-53\% [3]. If perforation of the esophagus was diagnosed later than two days after the injury, the mortality is approaching $100 \%$ [1]. 


\section{Materials and methods}

The study group consisted of 98 patients with penetrating injuries to the pharynx and cervical esophagus that underwent surgical treatment. Surgical interventions for perforations of the pharynx and cervical esophagus were performed under general anesthesia (endotracheal anesthesia).

Patients with esophageal wounds were hospitalized in the hospital department and had different approaches to treatment of penetrating injuries to the pharynx and cervical esophagus, resulting in an analysis of the two groups of victims.

In the comparison group, the traditional principles of intervention were used.

In the main group, surgical intervention was performed with a mini access on the neck 3-4 $\mathrm{cm}$ in length using a ring-shaped retractor. The defect of the pharynx and cervical esophagus was sutured in all cases. Tworow knot sutures was applied. In the presence of technical capability, the sutures were applied in the transverse direction. The location of injury was strengthened by local muscle tissue. Only active aspiration drainage was used, and the shutdown of the esophagus from the food passage was carried out by installing the probe.

\section{Results and discussion}

In the main group of patients with perforation of the pharynx and cervical esophagus used retractor mini-colotomy in 54 (96,4\%) patients and longitudinal colotomy according to Razumovsky - in $26(61,9 \%)$ patients in the comparison group.

In 10 patients in the main and in 4 patients in the comparison group, two-way longitudinal colotomy was performed to facilitate the inspection of the neck wounds.

In $2(3,6 \%)$ patients in the main group and in $16(38,1 \%)$ patients in the comparison group - only neck wounds that were already present were enlarged to the desired size for the inspection.

The combined injuries to the pharynx and cervical esophagus with other internal organs were $75,0 \%$ in the main group and $71,4 \%$ in the comparison group.

Ligation of the damaged blood vessels was performed the most often - in 16 patients in the main group and in 14 patients in the comparison group.

Tracheostomy was formed in 12 patients in the comparison group and in 6 patients - in the main group. The drainage of the pleural cavity was performed in 4 patients in each group. In case of injuries to the esophagus, the suturing of the perforation wall defect and the formation of the esophagostomy were performed. 
In the comparison group, the suturing of the perforation defect of the pharyngeal wall and cervical esophagus were performed only in the early time after the wound (up to $6 \mathrm{~h}$ ), in the absence of purulent-inflammatory events in the surrounding tissues.

In the main group, the defect of the pharyngeal wall and esophagus has always been sutured, regardless of the time that passed after the injury, and condition of the surrounding tissues. In this case, a ring-shaped retractor for mini-colotomy was used, two rows of sutures and the sutures line of the esophagus was strengthened by the cluster of surrounding tissues. Primary resection of the perforated esophagus in patients with neck injuries was not performed. In $56(100 \%)$ patients in the main group and in $24(57,1 \%)$ patients in the comparison group, suturing of the wall defect of the pharynx and esophagus was performed. In the main group in $6(10,7 \%)$ cases after the injury was more than 6 hours passed, in $2(3,6 \%)$ - more than 24 hours passed.

In $18(42,9 \%)$ cases in the comparison group, the defect of the pharynx and esophagus was not sutured at the late (more than 6 hours) detection of esophageal injury (6 patients) and with expressed inflammatory changes in the surrounding tissues (12 patients). So, there was implemented draining of the damaged area and formed esophagostomy.

In the main group, the retractor mini-colotomy for perforation of the cervical esophagus was completed by active aspiration drainage. The drainage tube was brought to the site of the injury of the esophagus and led to the skin through a contrapertura.

In the comparison group, passive drainage with polyvinylchloride tubes was widely used $-12(28,6 \%)$, flat latex outlet $-6(14,3 \%)$, a combination of tubular drainages with tampons $-22(52,4 \%)$.

To create functional rest of the esophagus, all 56 patients in the main group and 14 patients $(67,7 \%)$ in the comparison group with the perforation of the cervical esophagus were installed nasogastric probe. Gastrostomy by common techniques was formed in $14(33,3 \%)$ patients in the comparison group to exclude the damaged esophagus from the food passage.

As a result of surgical treatment of penetrating injuries of the pharynx and cervical esophagus in the main and the comparison group, the following results were obtained.

In the main group complications after surgical treatment occurred in $14(25,0 \%)$ patients, and in the comparison group - in $22(52,4 \%)$.

The analysis of the complications shows that in the comparison group, postoperative wound purulence $(42,9 \%)$ and neck abscess $(14,3 \%)$ were significantly more frequent than in the main group (14,3\% and 3,6\% respectively). The rate of development of acute mediastinitis in the comparison group was $9,5 \%$, and in the main group $-6 \%$; lung abscess $4,8 \%$ and $7,1 \%$ respectively, but these differences were not statistically 


\section{Збірник наукових статей}

significant. In addition, in the comparison group, there were purulent complications such as pleural empyema $(9,5 \%)$ and thrombosis a. carotis interna with ischemic stroke $(4,8 \%)$, which were not registered in the main group.

In each group, the failure of sutures of the pharynx developed in 2 patients. In both cases, the suturing of the defect of the pharyngeal wall was performed in the early period after injury (after 3 and 4 hours).

It was established that using the technique of mini-access in the main group did not increase the frequency of development failure of the esophageal sutures and amounted to 3,6\% (in the comparison group $8,3 \%)$. At the same time, the sutures on the injured esophagus in the main group were applied with signs of inflammation in 39,3\% of patients. This confirms the expediency of suturing the defect of the pharynx and cervical esophagus using the proposed methodology.

\section{Conclusions}

Complications in both groups were noted in 36 patients (36,7\%): 14 $(25,0 \%)$ patients in the main group and $22(52,4 \%)$ patients - in the comparison group.

In the main group, using the proposed surgical tactics contributed to a twofold decrease in the frequency of purulent complications after surgical treatment of penetrating damages of the pharynx and cervical esophagus, compared to the group where the treatment was performed according to traditional methods.

\section{References}

1. Доскалиев Ж. А. Миниторакотомия с эндовидеоподдержкой при заболеваниях органов грудной клетки / Ж. А. Доскалиев, А. И. Колос, О. Б. Оспанов и др. // Эндоскопическая хирургия. - 2005. - № $1 .-$ C. 43.

2. Кузнецов Я. О. Совершенствование методов лечения гнойных раневых поверхностей / Я. О. Кузнецов, Г. Я. Хулуп // Новости хирургии. - 2009. - Т. 17. - № 1. - С. 55-61.

3. Мирошников Б. И. Повреждения пищевода

Б. И. Мирошников, Г. А. Белый // Вестник хирургии им. И. И. Грекова. - 1998. - № 6. - С. 68-71.

4. Погодина А. Н. Клиника, диагностика и лечение повреждений пищевода и их последствий: Автореферат диссертации доктора медицинских наук / А. П. Погодина. - М., 1989. - С. 35.

5. Hinojar A. G. Management of hypopharyngeal and cervical oesophageal perforations / A. G. Hinojar, M. A. Diaz, Y. W. Pun, A. A. Hinojar // Auris. Nasus. Larynx. - 2003. - Vol. 30. - № 2. -P. 175182. 
Психолого-педагогічні проблеми становлення сучасного фахівця Випуск 2018

6. Jougon J. Esophageal perforation: life threatening complication of endotracheal intubation / J. Jougon, O. Cantini, F. Delcambre et al. // Eur. J. Cardiothorac. Surg. - 2001. - Vol. 20. - No. 1. - P. 7-10.

Максим Сизий, Олександр Шевченко, Віктор Лихман, Владислав Шевченко, Ігор Кулик. Тактика хірургічного лікування пошкоджень глотки та шийного відділу стравоходу.

Представлено результати хірургічного лікування 98 пацієнтів 3 проникаючими пошкодженнями глотки та шийного відділу стравоходу. Хворих були розподілено на 2 групи - основну та групу порівняння. У групі порівняння використовували традиційні принципи втручання. В основній групі оперативне втручання проводили з міні доступу на шиі 3-4 см завдовжки з використанням кільцевидного ранорозширювача. В основній групі гнійні ускладнення зустрічалися у 2 рази рідше, ніж у групі порівняння.

Ключові слова: шия, поранення, глотка, шийний відділ стравоходу.

Максим Сизый, Александр Шевченко, Виктор Лыхман, Владислав Шевченко, Игорь Кулик. Тактика хирургического лечения повреждений глотки и шейного отдела пищевода.

Представлены результаты хирургического лечения 98 пациентов с проникающими повреждениями глотки и шейного отдела пищевода. Больные были распределень на 2 группь - основную и группу сравнения. В группе сравнения использовали традиционные принципь вмешательств. $B$ основной группе оперативное вмешательство проводили мини доступом на шее 3-4 см длиной с использованием кольиевидного ранорасширителя. $B$ основной группе гнойные осложнения встречались в 2 раза реже, чем в группе сравнения.

Ключевые слова: шея, ранения, глотка, шейньй отдел пищевода.

Received 04.05.2018

Accepted 07.05.2018

Інформація про авторів:

Сизий Максим Юрійович - кандидат медичних наук, Головний лікар, КЗОЗ «Харківська міська косметологічна лікарня».

Шевченко Олександр Миколайович - кандидат медичних наук, асистент кафедри хірургії № 1, Харківський національний медичний університет.

Лихман Віктор Миколайович - доктор медичних наук, завідуючий відділенням хірургічних інфекцій, ДУ «Інститут загальної та невідкладної хірургії ім. В. Т. Зайцева НАМНУ».

Шевченко Владислав Олександрович - Харківський національний університет імені В. Н. Каразіна.

Кулик Ігор Анатолійович - кандидат медичних наук, Харківський національний медичний університет. 